inwards. It might be worth while to construct a light wooden framing that would cover one of the smaller walls of the National Gallery, to hang upon it pictures with dark backgrounds and then to tilt the screen forwards and note the improvement in visibility under the conditions of top lighting in use there.

\section{Museum Improvements}

Two articles of real value to museum curators appear in the Museums Journal for September. The first, by Dr. L. J. Spencer, discusses the artificial lighting of museum cases, and recommends the use of strip lights along the upper portion of the case, and the painting out of shadows cast by solid shelves. The assumption in such a case is that ordinary daylight lighting is ignored. Diagrams illustrate some of the cases of minerals in the British Museum lit by the method described, one tall (10 ft.) case showing a specially neat method of making use of the otherwise useless upper portion, by the fitting of transparent pictures illuminated from behind. In a second article, Mrs. Jean C. Stevens suggests a way of replacing the very expensive jointed figures used (where they can be afforded) for the display of costumes. With a little ingenuity effective figures can be made at a small cost, with cylinders of rabbit netting. The cylinders, head, arms, body, etc., can be 'bent' into shape as desired, and in proper position can be supported by strengthening struts of wire or wood. If the illustrations represent the results of this process, the home-made figures should find a comfortable home in many a museum, impoverished or otherwise.

\section{British Commercial Gas Association}

THE British Commercial Gas Association, founded for co-operative publicity effort in the gas industry, held its coming-of-age meeting in Leeds during the past week. Prince George, after seeing something of the manufacture of gas and gas appliances in the city, attended the dinner on Tuesday evening and gave an interesting review of the achievements of the industry. Major Geoffrey Kitson, in his presidential address, set forth further particulars of the present conditions, stating among other things that there are now five million 'slot consumers' on the books of the industry ; that $£ 180,000,000$ of money and a yearly consumption of $18,000,000$ tons of coal, are involved; and that 100,000 workmen are employed. He alluded to the advances being made in new directions, and in the afternoon, Mr. A. W. Smith, general manager and secretary of the Birmingham Gas Department, stated in his paper that authority has been obtained from the Home Office to run a test vehicle on the road with special steel cylinders containing gas at a pressure of $3000 \mathrm{lb}$. a square inch. It is hoped that gas so supplied may also be used for country houses and farms in districts remote from gas mains.

The executive chairman, Sir Francis Goodenough, at the opening of the Conference, spoke of the difficult days sure to follow upon the completion of the electricity grid, controlled by the Central Electricity Board. He foresees a desperate effort to get business for the grid "backed up more and more from Whitehall". It was in the gas industry that Sir Francis gained his first laurels as an authority on salesmanship and he insisted on the importance of perfecting the commercial side and of practising individual as well as collective enterprise. Major Kitson, who is chairman of the Leeds City Gas Department, urged the importance of gas and electricity, by co-partnership and concentration, setting themselves at once to achieve a national ideal of service in the most economical extraction of the potential heat, light and power from the great reservoir of energy-our sole native source-the coal fields. If the spirit and demeanour exhibited by Major Kitson prevailed more generally it would be a matter for congratulation. Extravagant ex parte statements by the advocates of the two agencies where their services overlap are greatly to be deplored, and they appear to be increasing. Among other things it is to be remembered that the exact measurement of the efficiency of heating appliances is still a subject of difficult scientific investigation. It is appropriate to say that in this and other technical problems, the University in the city where the Conference was held has long co-operated in a fruitful way with the Institution of Gas Engineers and that it has a chair of coal gas and fuel industries founded as a memorial to a great gas engineer, the late Sir George Livesey. In this and one or two other university centres in Great Britain, the scientific education of the gas engineer is now seriously taken in hand and is producing a long-needed type of recruit.

International Scientific Investigation of Population Problems

THE first World Population Conference was held under the auspices of the International Union at Geneva in 1928 and the second Conference at London in 1931. The proceedings of these Conferences have been published. In addition, three standing committees organise and to some extent subsidise research (The International Union for the Scientific Investigation of Population Problems : its Foundation, Work, Statutes and Regulations. Pp. 28. London: c/o Royal Geographical Society, 1932). It might perhaps be a matter for debate whether the results so far published justify a new and cumbrous organisation. But it is another matter when we take into account the value of an attempt to look at population problems from an intermational angle. All population problems have two aspects-a domestic and an international. The problem of emigration is a case in point. It may be that too much importance has been sometimes attributed to population movements, when, for example, war has been traced to over-population. But there can be no doubt that in many subtle ways population movements do affect international relations very profoundly. Thus if the Union can keep international aspects to the front, it will be justified whatever may be the value of the research which it directly advances. It may perhaps be said that in the long run the successful

No. 3284, Vol. 130] 
ordering of world affairs will depend upon the international handling of such matters as emigration and others with which the Union deals, and it may be hoped that the Union will prosper under the chairmanship of Sir Charles Close, who has succeeded Dr. Raymond Pearl in that office.

\section{Greek Earthquake of Sept. 27-28}

During the night of Sept. 27-28, a severe earthquake occurred in the Chalcidice district of Greece. Seven villages were entirely destroyed, more than 3000 houses were ruined, and 141 persons were killed and 403 wounded. In Salonica, several of the public buildings were damaged. From the brief accounts so far received, the epicentre seems to lie between Salonica and Mount Athos. Montessus, in his "Geographie Seismologique" (p. 253), defines three seismic zones in this part of Greece, near the towns of Salonica, Izvoro and Kavala, respectively, the recent earthquake being probably connected with the second of these zones. The shocks were strongly felt in Bulgaria, in the Strumitza valley, in or near which the great earthquakes of April 14 and 18, 1928, occurred, but the epicentres of these earthquakes lay about eighty miles to the north of the area recently disturbed.

\section{West Indian Hurricane Season of 1932}

THE West Indian hurricane season of the present year will rank as one of the notable ones, since two storms of the first magnitude have already been reported. The particulars of the more recent of these that have appeared in the Times of Sept. 28 indicate a phenomenon of an intensity very much above the average, the speed of the wind being said to have reached 120 miles an hour at times in Puerto Rico on Sept. 27, where at least two hundred people have been killed. The storm is said to have been even more destructive there even than that of Sept. 13, 1928 , and to have been the worst in the island's history. An official figure for the maximum speed of the wind will unfortunately not be available owing to the fact that the anemometer on the roof of the Weather Bureau at San Juan was destroyed with the tower on which it was mounted. The particulars given of the track do not indicate anything very abnormal. Many September storms pass to the south of San Domingo, as did the recent storm; they generally move towards west-north-west. In this case, however, the centre passed near the Virgin Islands and was on Sept. 28 apparently moving directly towards Jamaica, which suggests a nearly due westward motion. Such tracks are more common in August than in September and have generally passed close to the north coast of Yucatan to Mexico, without having begun the 'recurve' to a north-eastward movement characteristic of northern tropical hurricanes, which carries so many West Indian storms into the Gulf States.

\section{Cloudburst near Bakersfield, California}

A cloudBurst is reported to have occurred late in the night of Oct. I near Bakersfield, California, and to have caused water to advance like a tidal wave 40 feet high down a narrow cañon, sweeping away fifteen bridges, destroying railways and overturning locomotives, with considerable loss of life. Bakersfield lies within the American counterpart of the northern Sahara and the subtropical deserts of Arabia and Persia. The disaster must have occurred within or very near to an area with a mean annual rainfall of less than ten inches, which makes it appear at first sight the more remarkable. Cloudbursts are, however, regarded by meteorologists as nothing more than extreme examples of 'instability rainfall' of the thunderstorm type-they are in fact often accompanied by thunder-and their incidence in normally dry regions has therefore nothing very anomalous about it. The disastrous floods at Louth (Lincolnshire) on May 29, 1920, due to an exceptionally severe thunderstorm combined with an unfortunate accidental blockage of the narrow valley down which the water might otherwise have passed with little damage, occurred in one of the driest parts of the British Isles. The extent of the damage is often governed by such accidental circumstances, and it is interesting to note that a fall of rain at Cranwell (Lincolnshire) on July 11 of this year almost exactly equalled the heaviest fall measured in and around Louth on May 29, 1920, and came in a shorter time, without disaster.

\section{Climatic Changes in Central Asia}

THE theory that Central Asia, particularly the Tarim basin, furnishes evidence of progressive desiccation during historic times is refuted by Lieut.-Col. R. G. F. Schomberg in a paper on alleged changes of climate in Southern Turkestan in the Geographical Journal for August. Lop Nor, he maintains, is not drying up. Its change of level is due to the loss of the Qurug River water. That river changed its course and though its waters reach the lake they do so by a longer course via the Tarim River and so presumably are partly lost on the way. The Qurug is said now to have returned to its old course. Col. Schomberg gives reasons for denying that any of the rivers are drying except where increased cultivation calls for more irrigation water. He lays no value by the socalled evidence of depopulation in a land where the population is always sporadic and insecure. Dust storms, moving sand, and insect pests may easily cause abandonment of peopled sites. He denies that the many dead toghraqs or desert poplars necessarily imply want of water. Sometimes they are killed by the rapidly growing tamarisk, sometimes by disease and sometimes even by too much water. The paper is full of valuable arguments bearing on this muchdebated problem.

\section{New Antarctic Lands}

AFTER about a century's neglect the Enderby Land area of Antarctica was revisited in the summer of 1929-30 by Sir Douglas Mawson in the Discovery, of the British, Australian and New Zealand Antarctic Research Expedition, known for convenience as B.A.N.Z.A.R.E. The Discovery continued her work

No. 3284, VoL. 130] 